de, aceita e preconiza o emprego de medidas liminares, de natureza abertamente satisfativa e antecipatória da sentença de procedência, como se isto não negasse, por só, a ordinariedade e, portanto, o Processo de Conbecimento que somente existe enquanto ordinário, como o proclama o art. 162 do Código de Processo Civil. Quer dizer, amplia-se a distância entre os "dois direitos" que aludia Pontes de Miranda, o das universidades e o direito vivo praticado no foro. Para os compêndios, o mito da ordinariedade continua sendo louvado, enquanto aqueles que the enaltecem os méritos são primeiros a renegá-lo no foro.

14. As modernas correntes do pensamento jurídico europeu, especialmente a jurisprudência de seus tribunais, dão sinais, no entanto, de que buscam novas soluções que atendam ao princípio da instrumentalidad do processo, procurando torná-lo cada vez mais adequado às realidades e contingências peculiares ao direito material, cuja realização prática lhe cabe efetivar.

$\mathrm{Na}$ verdade, como sempre tem ocorrido na história do direito, mais do que a doutrina, foram as exigências de efetividade do processo - nascidas das solicitações e exigências da prática forense - o grande motor para o renascimento que já se observa, agor também nas manifestações mais lúcida de um grupo eminente de juristas, especia mente italianos, a propugnar pelo que se convencionou chamar tutela diferenciada que, a nosso ver, outra coisa não é senão o retorno o Direito Processual ao convívio forense; 0 resgate de seus vínculos e compromissos com o Direito Material; numa palavra, o abandono das gloriosas abstrações sistemáticas, com suas indefectíveis pretensões de verdades eternas que acabaram por transformar o Processo Civil numa ciência rigorosamente formal e tiranicamente redutora do direito material a seus pobres esquemas conceituais.

Segundo temos reiteradamente afirmado, arece-nos indispensável e urgente repensa velhas idéias e retomar o fio da evolução do pensamento jurídico que a submissão do Direito às metodologias próprias das ciências experimentais interrompeu, a partir do sonho do iluminismo europeu dos séculos XVII e XVIII.

E parece inevitável, a partir desta perspectiva de análise, que nosso velho conhecido, que atende pelo nome de Processo de Conbecimento - que outra coisa não é senão a reprodução do procedimento privado da actio romana, do ordo judiciorum privatorum, e sua esteriotipada ordinariedade - seja posto sob o crivo da análise, até mesmo para evitar sua total e completa destruição, risco a que sem dúvida ele ficará exposto, se a prática forense continuar ampliando, sem qualquer critério ou orientação teórica adequada, todas as formas legítimas e ilegítimas de "jurisdição de urgência".

\title{
Os elementos da ação
}

\section{José Maria Rosa Tesheiner}

Professor de Teoria Geral do Processo na Faculdade de Direito da UFRGS,

Juiz do Tribunal de Alçada do Rio Grande do Sul, ex-Consultor Geral do Estado.

SUMÁRIO

1. Elementos identificadores da ação; 2. As partes, elementos subjetivos da ação; 3. O pedido; 3.1. Pedidos concorrentes/concurso de ações; 3.2. Ação de consignação em pagamento versus ação de cobrança. Ação anulaconcorrentes/concurso de açoes; 3.2 . Açào de consignação em pagamento versus açăo de cobrança. Açấo anulaindividualização e da substanciação; 5 . Elementos que nāo identificam as açōes; 6 . Ações declaratórias; 7 . Açōes condenatórias; 8. Açōes constitutivas; 9. Ações mandamentais; 10. Ações executivas; 11. Identidade de ação/modificação da demanda; 12. Identificação de açōes; 13 . Conexão.

\section{Resumo}

Trata-se de um estudo sobre os elementos da ação, à luz da doutrina tradicional, adotada pelo Código de Processo Civil Brasileiro. $\mathrm{O}$ autor distingue os elementos identificadores da ação, isolando-os do interesse de agir e da invocação de norma jurídica abstrata, que, conquanto relevantes, não servem à sua identificação. Ligando-se à teoria da substanciação, o autor se detém no estudo dos fatos que constituem a causa de pedir, dividindo-os em simples, complexos, diversos de idêntica natureza e diversos de natureza diversa, para o efeito de determinar os que, preexistentes ou supervenientes, podem ser conhecidos, embora não alegados na inicial (CPC, arts. 462 e 131), bem como os limites da eficácia preclusiva da coisa julgada (CPC, art. 474). Ampla exemplificação é apresentada nos itens relativos às várias espécies de ações, segundo a categoria de sentença a que visam: declaratórias, condenatórias, constitutivas, mandamentais e executivas.

1. Elementos identificadores da ação

São elementos identificadores da ação: as partes, o pedido e a causa de pedir. A expressão utilizada deixa claro, desde logo, que há elementos da ação que não as identificam, como o "interesse de agir".
Com base nos elementos da ação se determinam:

a) os casos de cumulação de ações;

b) os fatos que podem ou não ser conhecidos em uma ação, sem que ela perca a sua identidade, transformando-se em outra. A alteração do pedido ou da causa de pedir é proibida (Código de Processo Civil, arts. 264 e 321), mas há fatos que o juiz pode conhecer, embora não alegados (art. 131), na inicial, entre eles o fato constitutivo superveniente (art. 462);

c) os casos em que há litispendência ou coisa julgada, a obstar uma segunda ação (art. 301, § §) - identifícação de aģões bem como os limites subjetivos e objetivos da coisa julgada, que atinge inclusive alegações não formuladas (art. 474). De maneira didática, o Código de Processo Civil estabelece:

- "Uma ação é idêntica à outra quando têm as mesmas partes, a mesma causa de pedir e o mesmo pedido" (art. 301, § $2^{\mathrm{a}}$ ).

"Há litispendência, quando se repete ação, que está em curso" (art. 301, § 3을 primeira parte).

- "Há coisa julgada, quando se repete ação que já foi decidida por uma sentença de que não caiba recurso" (art. 301, $\S 3^{\circ}$, segunda parte);

d) as hipóteses de conexão e de continência (arts. 103 e 104).

R. Fac. Direito UFRGS, Porto Alegre, 10: 213-231, jul. 1994 


\section{As partes, elementos subjetivos}

da ação

São partes, em sentido formal, o autor e o réu, isto é, aquele que pede, em nome próprio, a prestação jurisdicional e aquele contra quem ou em face de quem o autor formula o seu pedido, ou a pluralidade de autores ou de réus, litisconsortes ativos ou passivos.

São partes em sentido material os sujeitos da relação interpessoal que a sentença irá regular diretamente.

Em geral há coincidência: as partes em șentido formal o são também em sentido material, como no caso em que o autor, afirmando-se credor do réu, pede a condenação deste, apontando-o como devedor. Há, porém, casos excepcionais, em que se admite que alguém esteja em juízo, como autor ou como réu, na defesa de direito alheio. Tem-se, então, a chamada substituicão processual. Aquele que pleiteia, em nome próprio, direito alheio, é substituto processual, parte em sentido formal. Aquele cujo direito se encontra sub judice é o substituído, parte em sentido material. Assim, no caso de babeas-corpus impetrado em prol de outrem, o impetrante é parte em sentido formal e o paciente, parte em sentido material.

Outro caso: o réu, no curso do processo aliena a coisa litigiosa. Em face do artigo 42 do Código de Processo Civil, ele mantém a sua posição de réu, no processo. Entretanto, desde a alienação, já não é o seu direito de propriedade que está em jogo, mas o do adquirente. Assim, desde a alienação, o réu, alienante, assume a condição de substituto processual; o adquirente, a de substituído. Este, embora não sendo parte em sentido formal, sofre diretamente os efeitos da sentença. Julgada procedente a ação, o autor poderá, na execução, tirar do adquirente a coisa litigiosa, sem que este possa se subtrair aos efeitos da sentença, alegando sua condição de terceiro. A própria imutabilidade, decorrente da coisa julgada, apanha não só as partes em sentido formal, mas também as que o são em sentido material.

Há quem condene a expressão "parte em sentido material", com o argumento de que implica afirmação da existência de direito subjetivo, segundo o direito material. Entretanto, é claro que apenas por elipse é que se afirma que o substituto defende direito do substituído. Subentende-se que se trata de direito alegado, ou seja, de alegação de direito e não de direito certo. Todavia, exista ou não direito subjetivo no plano do direito material, certo é que a sentença irá regular relação interpessoal em que figuram, de um lado o substituído e, de outro, a parte adversa. Aliás, a sentença, norma concreta, assim como a lei, norma abstrata, não existe senão para regular relações interpessoais, ou seja, para regular o convívio entre pessoas.

$\mathrm{O}$ artigo 472 do Código de Processo $\mathrm{Ci}$ vil estabelece que "a sentença faz coisa julgada às partes entre as quais é dada, não beneficiando nem prejudicando terceiros". "Qualquer sentença pode, por efeito reflexo, beneficiar ou prejudicar terceiro. Assim, julgada procedente ação de reivindicação, credor do réu vencido fica impedido de penhorar a coisa reivindicada, que antes garantia o seu crédito. Isso, porém, não significa que a sentença produza coisa julgada também para o credor da parte. Não era direito seu que se encontrava sub judice. Pode ele, pois, afirmando-se proprietário, reivindicar do vencedor a coisa, sem que este tenha em seu prol a exceção de coisa julgada".

"Terceiros", diz José Frederico Marques, "não são todos os que foram estranhos ao processo, porque dele não participaram, nem para tanto foram citados: o sucessor a título universal ou singular, por exemplo, não é terceiro em relação à decisão passada em julgado (Código de Processo Civil, art. 658)." (Manual. São Paulo, Saraiva, 1974, v. III, pág. 241)

Numa fórmula concisa, podemos dizer que a sentença faz coisa julgada às partes, ao substituído, bem como aos seus sucessores.
A diversidade da posição processual das partes não prejudica a identidade. Ainda que o autor de uma das ações seja réu na outra, e vice-versa, há identidade de partes.

\section{O pedido}

São elementos objetivos da ação o pedido e a causa de pedir.

Distinguem-se o pedido imediato, que corresponde à natureza do provimento solicitado, e o pedido mediato, correspondente ao teor ou conteúdo do provimento.

Quanto à natureza, tem-se que o provimento solicitado pode ser um ato declarativo ou de outra natureza, ou seja, um "fazer", como ocorre na justificação, em que se pede ao juiz que ouça testemunha e certif que suas declarações.

Quanto aos efeitos, o provimento, de natureza declarativa, se dirá declaratório, constitutivo, condenatório ou mandamental, conforme o efeito que predomine.

O provimento solicitado pode ser um ato de execução. Introduz-se, aqui, como terceira espécie, uma nova classificação, porque executar não se opõe nem a declarar nem a fazer, já que tanto pode haver execução por declaração (v.g., execução das obrigações de prestar declaração de vontade), quanto po atos de modificação do mundo físico (v.g. busca/apreensão/entrega de coisa móvel).

Pedido mediato é o bem material ou imaterial pretendido pelo autor.

Para que se reputem idênticos dois pedidos, é preciso que sejam os mesmos imediato e mediato. Pedido de sentença declaratória não é idêntico ao de condenação. Portanto, a existência de anterior ação declaratória não é óbice à propositura de ação condenatória. A recíproca, porém, não é verdadeira, porque o pedido de condenação contém o de declaração.

Há identidade de pedidos, no caso de ações contrárias, como no caso de $A$ pedir a declaração da existência de relação jurídica e $B$ lhe mover ação para a declaração da inexistência da mesma relação.

Julgada improcedente ação declaratória negativa, posterior ação de cobrança, pro- posta pelo vencedor, já contará, em seu prol, com a coisa julgada decorrente da declaração da existência do crédito.

Julgada procedente a ação de cobrança, não se admite posterior ação de repetição de indébito, proposta pelo vencido, porque nesta se contém pedido de declaração in compatível com a coisa julgada decorrente da sentença anterior.

Pedido imediato, de natureza declaratória, exige sujeito e predicado. Assim, na ação declaratória da nulidade do contrato $\mathrm{X}$, o teor do provimento solicitado é "o contrato X é nulo"; a expressão "é nulo", isoladamente, não tem sentido. Não seria correto, nesse caso, afirmar-se que "o contrato $\mathrm{X}$ " integra a causa de pedir, e a sanção de nulidade, o pedido.

Também entendo que, nas ações condenatórias e de execução, o título da dívida integra o pedido, e não a causa de pedir. Isso porque dizer-se que se quer a condenação do réu em 1.000 ou que se quer executá-lo pela quantia de 10.000 , importa formular-se pedido incompleto e obscuro. Assim, nos casos indicados, o teor ou conteúdo do provimento se completa com a indicação de que se quer a condenação do réu no pagamento da quantia de 1.000 , correspondente ao aluguel de setembro do prédio $\mathrm{X}$ ou que se quer executá-lo pela quantia de 10.000 , correspondente ao principal e juros da nota promissória Y. Ainda mais clara fica a necessidade de se integrar no pedido o título da dívida, se pensamos na hipótese de condenação em quantia ilíquida. Efetivamente, dizer-se que se pretende a condenação do réu em quantia indeterminada em dinheiro significa pouco mais que nada. $O$ conteúdo do provimento solicitado somente se torna claro se acrescentamos que se trata da quantia correspondente aos danos materiais decorrentes do acidente $Z$.

\subsection{Pedidos concorrentes} concurso de ações

Trata-se de pedidos que concorrem entre si, eventualmente um excluindo o outro. 
Um dos casos é o de continência, em que o pedido maior absorve o menor. Outro, o de pedido de declaração contrária. Formulado o pedido de declaração de nulidade de negócio jurídico, há litispendência imped tiva da propositura, pela parte contrária, de ação declaratória da validade do contrato, entendendo-se, nessa hipótese, que há identidade de pedidos, embora com sinais contrários, positivo e negativo.

Há, finalmente, o fenômeno estudado por Chiovenda, sob o título de "concurso de açōes" (Instituições. I/136):

$1^{\underline{a}}$ hipótese: mesma causa de pedir, mesmo pedido, partes diversas, como nas obrigaçōes solidárias. A ação do credor contra um dọs devedores solidários não é idêntica à ação do mesmo credor contra outro devedor solidário. Não há, pois, o óbice $d a$ litispendência, mas a satisfação do credor, em uma das ações, determina a extinção da outra, por desaparecimento do interesse de agir. Em embargos à execução ou à arrematação, poderá o executado alegar o pagamento entrementes feito pelo co-devedor solidário.

$2^{2}$ hipótese: mesmas partes, mesmo ped do, causas diversas. $O$ pedido de proteção possessória não exclui o petitório, mas, "na pendência do processo possessório é defeso assim ao autor como ao réu, intentar ação de reconhecimento do domínio" (CPC, art. 923). O trânsito em julgado da sentença de procedência dos embargos do devedor, com a conseqüente extinção da execução, fundada em cambial, não impede a propositur de ação condenatória, do mesmo credo contra o mesmo devedor, para haver o mesmo crédito que justificara a emissão da cambial.

$3^{\text {a }}$ hipótese: mesmas partes, mesma causa de pedir, pedidos diversos, porém tendentes ao mesmo resultado econômico,

Suponha-se que o locador proponh duas açōes, relativas ao mesmo alugue: uma condenatória e a outra, de execução. Ora, o pedido de execução, se cabível, torna inútil a condenatória, que deve ser extinta por falta de interesse.
Nos casos de ação redibitória e quanti minoris e de ação para haver a própria cois e outra, para haver o equivalente ou perdas e danos, há, aparentemente, diversidade de pedidos. Atende-se, porém, à identidade essencial. Por isso, Chiovenda ensina que "o autor pode promover uma ação e passar, no mesmo processo, a outra, sem mudança de ação para a ex tear em segunda a resolução. Pode também propor as duas ações em conjunto, uma subordinada à outra, ou alternativamente. Depende da natureza das diversas obrigações alternativas, em que a escolha compete ao autor, que a escolha de uma ação exclua ou não a outra." Do exposto se segue que, proposta a ação redibitória, a posterior propositura da quanti minoris se defronta com óbice da litispendência.

O deferimento da penhora torna inútil o pedido de arresto dos mesmos bens, relativamente à mesma dívida.

A ação de consignação em pagamento não exclui a de cobrança, mas a procedência de uma importa na improcedência da outra.

$O$ trânsito em julgado da sentença condenatória impede a propositura da ação de repetição do indébito, por obstáculo decorrente da coisa julgada material

3.2. Ação de consignação em pagamento versus ação de cobrança. Ação anulatória de débito versus execução

A sentença que julga procedente ação de consignação em pagamento produz coisa julgada material, impeditiva de execução fundada no título que se declarou quitado Isso, porém, não significa que sejam idênticas a ação de consignação em pagamento e a de cobrança ou de execução.

A ação de consignação em pagamento não induz litispendência em relação à de cobrança, tenha esta ou não caráter executivo, porque há diversidade de pedidos.

Julgada improcedente a ação de consignação em pagamento, o devedor pode levantar a importância depositada, ainda que parte adversa se afirme credora de maior quantia. O credor poderá, porém, impedir o levantamento, arrestando ou penhorando a quantia depositada.

Há, sim, identidade entre a ação de consignação em pagamento e os embargos que o devedor ofereça, na execução, com base naquela ação. Em ambas o devedor pede que se declare extinto o débito, em face do depósito em pagamento. Significa isso, não que o devedor fique impedido de oferecer embargos à execução, em face da litispendência, mas sim que tais embargos não precisam ser opostos: tendo notícia da existência da consignação em pagamento, o juiz deve suspender a execução, independentemente de embargos. Se transitou em julgado a sentença que acolheu a consignação, cabe ao juiz extinguir a execução, mesmo de ofício, por falta de título executivo.

Mutatis mutandis, a mesma é a solução no caso de ser proposta ação de execução, na pendência de ação anulatória do débito em que ela se funda. No caso particular de execução fiscal, a Lei é expressa: "A propositura de ação anulatória de débito fiscal não inibe a Fazenda Pública de promover -lhe a cobrança" (CPC, art. 585, § $\left.1^{\circ}\right)$. Se, em vez de execução, foi proposta ação ordi nária de cobrança, não há que se aplicar a pena de revelia. Mesmo não sendo esta contestada, impõe-se o regular processamento das duas ações.

\section{A causa de pedir}

É, dos elementos da ação, o mais difícil de precisar. A ela se refere o Código de Processo Civil, ao exigir que o autor, na petição inicial, indique o fato e os fundamentos jurídicos do pedido (art. 282, III)

Para Chiovenda, causa de pedir é o fundamento, a razão de uma pretensão (Inst.I/358), isto é, do pedido do autor.

Antes de mais, excluamos, ensina Chiovenda, "que a causa petendi seja a norma de lei invocada pela parte em juízo. Individua-se e identifica-se a ação por meio dos elementos de fato (...) e não pela norma abstrata de lei. Por conseqüência, a simples mudança do ponto de vista jurídico (ou seja, a invocação duma norma diferente no caso de que um fato possa incidir em dife rentes normas de lei) não importa diversidade de ações; é lícita, portanto, assim à parte como ao juiz." (Inst., I/111 e ss.)

Daí se segue que, no caso de concurso de normas, que se verifica quando o mesmo fato pode incidir em normas diferentes e se trata de averiguar qual é aplicável, cabe ao juiz decidir e de ofício (iura novit curia) "Assim no caso, praticamente freqüente, em que um viajante exija do condutor o ressarcimento dos danos sofridos durante o transporte. Quer se trate de responsabilidade aquiliana ou contratual, é questão de norma invocável: na realidade, porém, uma é a ação. Invocado o art. 1.151, Cód. Civi (equivalente ao art. 159 do Código Civi Brasileiro), nem se vedaria à parte invocar, nem ao juiz aplicar as normas sobre a responsabilidade contratual." (Inst.,I/111 e ss.).

Tenho por certo que a norma abstrata invocada pela parte como fundamento de sua pretensão não integra a causa de pedir, não sendo, pois, elemento identificador da ação. Tenho também por certo que se o passageiro move ação de indenização contra o transportador, fundada em culpa, pode o juiz acolher o pedido, com fundamento no contrato de transporte, isto é, afirmando a responsabilidade objetiva do transportador, porque, nessa hipótese, simplesmente se despreza o fato "culpa", que terá sido invocado como um plus juridicamente irrelevante. Entretanto, não são idênticas as ações em que o autor pede indenização, a primei ra com fundamento exclusivo no contrato de transporte e a segunda com fundamento na culpa. A imprudência, negligência ou imperícia são fatos que, por suposto, não foram alegados na primeira ação e haveria manifesto cerceamento de defesa se o réu fosse nela condenado por fato de que não foi chamado a se defender. Por outro lado, não seria razoável exigir-se, sob pena de preclusão, que o autor propusesse ação fundada também na culpa, cuja prova é quase sempre difícil, tendo ele o entendimento de 
que a responsabilidade decorreria simplesmente do contrato de transporte.

Para Carnelutti, causa de pedir, isto é, aquilo que permite, a quem propõe uma ação afirmar que tem razão; não é nem o ato, nem a norma jurídica, mas a afirmação da coincidência do fato com o suporte fático de uma norma. Embora o fato e a norma componham a causa de pedir, não têm ambos igual eficácia vinculante para o juiz, porque se combinam, aí, o princípio dispositivo e a máxima "curia novit iura" (Trattato, pág. 172).

Tenho por certo, como já afirmei, que a norma abstrata invocada pela parte não integra a causa de pedir, motivo por que afasto essa lição.

Conforme Liebman, causa de pedir é o fato ou relação jurídica que o autor põe como fundamento de sua demanda (Manua$l e, \mathrm{I} / 172)$. Como a relação jurídica decorre da incidência de norma jurídica sobre fato, poderíamos ser tentados a excluí-la, como elemento autônomo da causa de pedir. A causa se reduziria, então, aos fatos. Há, porém, nesse passo, que se apontar para uma sutileza: se o pedido é de sentença que se pronuncie, com força de coisa julgada, sojurídica, é claro que a causa de pedir não pode senão assentar no fato gerador dessa mesma relação. Nesse caso, a relação jurídica integra o pedido, e não a causa de pedir. Todavia, se o pedido é de sentença outra (v.g., decretação de despejo), a necessidade de o juiz se pronunciar incidenter tantum sobre a existência ou inexistência de relação jurídica não impende que esta, como tal, integre a causa de pedir. Assim, na retomada para uso próprio, a propriedade do imóvel locado pode ser posta por lei como requisito para a decretação do despejo e, nesse caso, a relação jurídica de domínio integra a causa de pedir, não a integrando, porém, o fato gerador dessa mesma propriedade, embora possa eventualmente ser necessário que o juiz o examine, para afirmar ou negar, incidenter tantum, a propriedade do autor. Recorde-se, a propósito, o disposto no artigo 469, III, do Código de Processo
Civil: não faz coisa julgada a apreciação de questão prejudicial, decidida incidentemente no processo.

4.1. Consideraģóes sobre os fatos

O fato, enquanto evento histórico, é imutável e compreende a totalidade de seus elementos, todos igualmente relevantes e imutáveis. Mudá-los implicaria alteração do passado.

Já a descrição do fato, ou versão, contém apenas alguns dos elementos do fato e se apresenta mutável. Pode-se acrescentar um elemento antes omitido ou omitir outro antes incluído e mesmo inventar circunstâncias falsas.

Supõe-se que entre o fato e a versão exista um mínimo de identidade, embora se saiba possível uma fantasia total: uma "versão" com nenhum elemento de conexão com o evento histórico.

São versões de um mesmo fato as que apresentam suficientes elementos comuns (elementos de conexão). Múltiplas versões de um mesmo fato se reconhecem por seus elementos de conexão, idênticos em todas. É possível que haja um único elemento de conexão, mas suficiente para que se possa referir duas ou mais versões ao mesmo evento histórico.

Versões que não apresentam suficientes elementos de conexão, entende-se que se referem a eventos diversos. Se, por exemplo, a versão $X$ afirma que o veículo $A$ colidiu com o veículo $B$ e a versão $Y$ afirma que $A$ colidiu com $C$, havendo $B$ colidido com $D$, em outra hora e local, os elementos comuns (veículos A e B abalroados) são insuficientes para referir as duas versões a um evento único.

Qualificar juridicamente um fato é destacar alguns elementos da versão, para a determinação de seus efeitos jurídicos.

Por fato jurídico entenda-se um evento, dentro de coordenadas do tempo e do espaço. A incompatibilidade de normas (v.g. inconstitucionalidade de lei) não é um fato, porque, aí, o confronto se dá no plano lógico-normativo.
O fato jurídico produz efeitos jurídicos. Ao decompô-lo, nele podemos encontrar: uma conduta, omissiva ou comissiva, lícita ou antijurídica, dolosa ou culposa; uma relação de causalidade ou de finalidade entre uma conduta e um resultado; uma relação de causalidade entre um evento e um resultado;

. um fato transeunte

um estado de fato.

Ao se qualificar juridicamente um fato, trabalha-se com um núcleo, geralmente expresso por um verbo, e com elementos outros (matar, matar feto humano, matar em legítima defesa, matar para roubar; adquirir coisa furtada, sabendo-a furtada; adquiri coisa furtada, devendo sabê-la furtada).

O verbo do núcleo pode ser mudado, como na substituição de "subtrair coisa alheia" por "apropriação de coisa alheia" (subtração de coisa de que se tem a posse ou detenção)

É sabido que, ao se qualificar juridicamente um fato, o acréscimo ou omissão de algum elemento pode determinar profundas mudanças de efeitos jurídicos.

O fato jurídico pode ser simples ou complexo.

No fato, ainda que simples, se compreendem as suas circunstâncias e seus efeitos.

O fato complexo é constituído de eventos diversos, que se somam, no que se refere à produção de efeitos jurídicos. Constitui uma unidade jurídica.

Evidentemente há eventos diversos que não constituem unidade jurídica, produzindo cada qual seus efeitos jurídicos próprios. Podemos distinguir quatro situações, agrupando os eventos diversos (a) da mesma natureza ou (b) de diversa natureza, a produzir (c) o mesmo efeito jurídico ou (d) efeitos jurídicos diversos, ainda que iguais.

A danificação dolosa do imóvel e a sublocação não consentida são exemplos de eventos de natureza diversa, a produzir o mesmo efeito jurídico: decretação do despejo do locatário.

A danificação das paredes do imóvel e a danificação de suas portas são exemplos de eventos da mesma natureza, a produzir idêntico efeito jurídico: despejo.

Os mesmos fatos, referidos à indenização cabível, são exemplos de eventos diversos, da mesma natureza, que produzem cada qual o seu efeito jurídico próprio (o valor correspondente à indenização das paredes não se confunde com o da indenização das portas).

\subsection{Teorias da individualizaşão e da} substanciaşãa

Conforme a antiga teoria da individualização, a causa de pedir seria constituída sempre pela relação jurídica invocada pelo autor, como fundamento do pedido. Ainda que os fatos fossem os mesmos, outra seria causa de pedir, se diversa a relação jurídica invocada.

Criticou-se esse posicionamento, primeiro, por exigir do autor um conhecimento preciso do direito objetivo, o que a Lei não exige; segundo, porque a indicação do autor não tem relevância, já que ao juiz incumbe a qualificação jurídica dos fatos; terceiro, por não se lograr identificar a ação, já que da mesma relação se podem deduzir múltiplas pretensões, v.g., prestação $\mathrm{X}$, prestação $Y$, anulação, rescisão. (Cf. Lent, Trattato. p. 160; Rosenberg. Tratado. v. II, $\S 88, n$. III).

A teoria hoje predominante é a da substanciação, que dá prevalência aos fatos alegados pelo autor.

Causa de pedir, ou título, é o conjunto dos fatos necessários para deduzir, com base em norma jurídica, que o autor é titular de um direito violado pelo réu. E o conjunto dos fatos com base nos quais se pode, se provados, afirmar a procedência da ação.

Se os fatos são os mesmos, não se altera a causa de pedir, ainda que outra seja a norma jurídica invocada. Assim, pleiteada a devolução de uma coisa com a afirmação de haver se configurado contrato de em préstimo, pode o juiz acolher o pedido, ainda que entenda de qualificar o contrato como de socieade. 
"Chama-se a atenção para o texto da lei. O Código exige que o autor exponha n inicial o fato e os fundamentos jurídicos do pedido. Por esse modo faz ver que na inicial se exponha não só a causa próxima - o fundamentos jurídicos, a natureza do direi to controvertido - como também a caus remota - o fato gerador do direito. Quer dizer que o Código adotou a teoria da substanciação, como os códigos alemão e aus tríaco. Por esta teoria não basta a exposição da causa próxima, mas também se exige da causa remota." (Moacyr Amaral Santos. Primeiras Linbas. $5^{\underline{a}}$ ed., São Paulo, Saraiva, 1977, v. I, pág. 142)

Como diz Liebman, "a causa petendi, ou causa da ação, é o seu fundamento jurídico". O que a constitui são os fatos jurídico com que o autor fundamenta o seu pedido. Trata-se, portanto, habitualmente, "do fato constitutivo da relação de onde o autor deduz a sua pretensão, juntamente com fato que dá lugar ao interesse de agir."

Nesse assunto, duas correntes se formaram para identificar a causa petendi: a da substanciação, que sustenta ser necessário a alegação do fato constitutivo do pedido, a da individualização, para a qual é bastante a relação de direito afirmada pelo autor para se individualizar a ação.

Em nossa legislação foi adotada a teoria da substanciação, pois o artigo 282, III, do novo Código de Processo Civil; ao tratar da causa petendi a ser exposta na petição escrit com que se propõe a ação, menciona expressamente o fato (causa remota) e os fundamentos jurídicos do pedido (causa próxima). (José Frederico Marques, Manual. São Paulo, Saraiva, 1974, v.I., pág. 155)

Embora predomine a teoria da substanciação, autores de muito prestígio entr nós, como Chiovenda e Liebman, filiam-se à teoria da individualização, pelo menos no que concerne às ações em que se invoca direito absoluto.

Diz Chiovenda: "Na ação real, basta a afirmação da relação jurídica (...). Por conseguinte, a causa na reivindicação não é um ou outro modo de aquisição, mas o fato atual da propriedade; a questão jurídica ver- sa sempre sobre a existência do direito de propriedade, ainda quando a questão lógica e restrinja ao ponto, por exemplo, de mo se pode dizer dos outros direitos absolutos." (Inst. I. págs. 11 e ss).

"Diz Liebman (...) que, nas ações reais, 'a causa se encontra no direito real sem se levar em conta o título específico de aquisição do referido direito: o título de aquisição pode mudar sem que se altere a causa petendi, pois o direito de propriedade é sempre o mesmo, qualquer que seja o fato de que derive'." (José Frederico Marques. Ma nual. São Paulo, Saraiva, 1974. v.I, p. 155).

Observa José Ignácio Botelho de Mesquita que as teorias da substanciação e da in dividualização têm vários pontos de contato. "Em um ponto, porém, elas se tornam irredutíveis. Esse ponto onde ambas se afastam é precisamente a afirmação do que se deva entender por causa petendi nas açōes propostas com fundamento em um direito de caráter absoluto, assim denominados pela teoria da individualização os direitos reais e os direitos de família, e os decorrentes do estado da pessoa."

Sua conclusão, nessa parte coincidente com a da teoria da substanciação, é que, mesmo nas ações fundadas na alegação de um direito real, não basta a indicação da relação jurídica (propriedade, servidão, usufruto), para a determinação da causa petendi, sendo necessária a indicação do fato constitutivo. E com acerto pondera ser essa a razão pela qual ação reivindicatória de imóvel, em cuja inicial o autor se afirme proprietário em decorrência de contrato de compra e venda, pode e deve ser julgada improcedente, sem prejuízo de vir depois a ser julgada procedente ação fundada no fato constitutivo do registro. José Ignácio Botelho de Mesquita. $A$ causa petendi nas açoes reivindicatórias. Ajuris. Porto Alegre, (20): 166-80, nov. 1980)

Tenho como mais adequada a teoria da substanciação, mesmo com referência ao direitos reais. Julgada improcedente ação declaratória da propriedade fundada em título de domínio, não se há de obstar uma segunda ação, fundada em usucapião, aind que consumado anteriormente à propositura daquela. Com Moacyr Amaral Santos, afirmo que "mesmo no tocante às ações reais, a causa de pedir compreende não só a causa próxima, o domínio do autor (...) como também a causa remota, o modo de aquisição do domínio, qual o seu título de aquisição." (Primeiras Linhas. $5^{\underline{a}}$ ed. São Paulo, Saraiva, 1977. v.I, p. 142)

A afirmativa de que a causa de pedi consiste nos fatos jurídicos invocados pelo autor como fundamento de seu pedido não inteiramente precisa.

Efetivamente, o artigo 474 do Código de Processo Civil dispõe: "Passada em julgado a sentença de mérito, reputar-se-ão deduzidas e repelidas todas as alegações e defesas, que a parte poderia opor assim ao acolhi mento como à rejeição do pedido." Há, pois, fatos que, embora não alegados, de vem ser tidos como virtualmente compreendidos na causa de pedir. $O$ dispositivo citado impede que o autor, vencido em uma ação, proponha outra, com idêntico pedido, alegando fato diverso, mas virtualmente compreendido na mesma causa de pedir. Entendo que tais são os eventos diversos, da mesma natureza, conducentes ao mesmo efeito jurídico. Assim, se o autor pede despejo, alegando danos nas paredes do imóvel, não pode propor outra, alegando danos nas portas, salvo se ocorridos após o encerramento da instrução. Não se lhe veda, porém, a propositura, concomitante ou posterior, de ação de despejo fundada em locação não consentida, porque se trata de fato de natureza diversa. Claro, outrossim, que o pedido de indenização dos danos nas paredes não impede posterior pedido de indenização dos danos nas portas (fatos de idêntica natureza, mas produzindo cada qua seus efeitos jurídicos próprios, ainda que iguais). Incide, na hipótese, o artigo 294 do Código de Processo Civil: "Quando o auto houver omitido, na petição inicial, pedido que lhe era lícito fazer, só por ação distinta poderá formulá-lo."
5. Elementos que não identificam as ações

Em primeiro lugar, não serve à identificação da ação a norma abstrata invocada pelo autor. Por isso, nada impede que o juiz aplique norma diversa. Da mibi factum tibi dabo jus.

Também não a identificam as condições da ação, suposto que se não as confundam com o mérito. Julgado o autor carecedor da ação, pode ele renová-la, quer se mantenha idêntica a situação, quer se haja suprido entrementes a condição que antes faltava. Em qualquer dos casos, é a mesma ação que se renova (CPC, art. 268), o que mostra que a modificação de elemento que integre condição da ação não serve para distinguir uma de outra.

$O$ fato de se haver, em um primeiro processo, afirmado a impossibilidade jurídica do pedido, não impede que se afirme a possibilidade, em outro, subseqüente. Há, nesse caso, renovação da mesma ação, expressamente autorizada por lei (CPC, art. 268 , combinado c/art. 267, VI).

Quanto ao interesse de agir, há uma distinção a se fazer: Se antes se afirmou a desnecessidade da tutela jurisdicional e, em novo processo, afirma-se a necessidade ou utilidade da tutela pretendida, não há dúvida de que a ação permanece a mesma, o que mostra que a variação de tal elemento não serve para distinguir uma ação de outra. Se, porém, o que se afirmou foi a inadequação do provimento solicitado (v.g., pedido de cautela para a composição definitiva da lide), outra será a ação em que se peça o provimento adequado, porque, aí, há alteração do pedido (pedir arresto não é o mesmo que pedir execução).

No que tange à legitimação para a causa, há renovação da mesma ação, e não propositura de outra ação, se antes se negou e agora se afirma a legitimação da parte. Todavia, a legitimidade em sentido chiovendiano (titularidade do direito ou da obrigação) envolve o mérito e constitui elemento identificador da ação. Se o juiz rejeita pedido de indenização, porque o autor não 

ficado em acidente de trânsito, pode o autor propor outra, afirmando-se comodatário que pagou os danos ao comodante. A causa de pedir é diversa.

Por fim, é a mesma ação que se renova, depois de implementada a condição, no caso de voltar o autor a juízo, com a prova do exercício da pretensão (v.g., notificação premonitória, para o exercício da ação de despejo), ou de depósito preparatório ou exibindo titulo executivo cuja existência antes alegara sem exibi-lo.

\section{Ações declaratórias}

Inicialmente, algumas precisões terminológicas. Seja a sentença: "Declaro que o contrato $\mathrm{X}$ é nulo, porque celebrado por meno de 16 anos". Podemos distinguir, aí, a natureza do provimento (declaro), o teor ou conteúdo do provimento (o contrato $\mathrm{X}$ nulo) e a causa de pedir (porque celebrado por menor de 16 anos). Podemos, ainda desdobrar o conteúdo do provimento, nel distinguindo seu objeto (o contrato $\mathrm{X}$ ) e o atributo (é nulo).

Podemos imaginar que a nulidade dess mesmo contrato seja declarada porque cele brado por instrumento particular ou por dispor sobre a herança de pessoa viva. Em todos os casos, a causa de pedir é fato que se enquadra no suporte fático de norma jurídica que estabelece a sanção de nulidade. Há, na hipótese, três ações distintas, correspondentes a três causas de pedir diferentes. A propositura ou o julgamento de uma não obsta o ajuizamento de outra. Não há litispendência nem coisa julgada.

Nesse primeiro exemplo, deparamo-nos com a hipótese normal, em que o juiz declara a incidência de norma jurídica sobre fato. Examinamos a seguir as hipóteses excepcionais, em que o pronunciamento do juiz recai apenas sobre norma ou unicamente sobre fato.

$\mathrm{Na}$ ação direta de inconstitucionalidade não há causa de pedir, porque não há alegação de fato de que se extraia como conseqüência o pedido. Diria alguém que se ped a declaração de inconstitucionalidade por infração a tal ou qual dispositivo da Constituição. Isso, porém, não passaria de redundância: lei inconstitucional por contrariar dispositivo da Constituição. E de se perguntar, porém, se é concebível a existência de ação, sem a existência de um de seus ele mentos essenciais. Como a resposta evidente é que não, restam apenas as alternativas (a) de negar à ação direta de inconstitucionalidade a natureza de ação, possivelmente com a observação de que se trata de atividade de natureza legislativa mais que jurisdicional, ou (b) de afirmar o caráter meramente acidental da causa de pedir. Sem renegar a primeira solução, acolho a segunda. A causa de pedir, nas ações declara tórias, é o fato de que decorre a existência do direito subjetivo cuja declaração se pede. Se não há direito subjetivo a ser afirmado ou negado, causa de pedir não há. Resta, sim, para explicar o pedido, o interesse de agir que, como vimos, não é elemento identificador da ação. Tais afirmações devem ter certo cunho de evidência para quem, como Araken de Assis, tem como indiscutível que nosso Código de Processo Civil (a) adotou a teoria da substanciação; (b) a ação de que se cogita, ao se falar em "elementos da ação" ou em "cumulação de ações" é, na terminologia de Pontes de Miranda, a ação de direito material. (Cf. Araken de Assis. Cumulaşão de açôes. São Paulo, Revista dos Tribunais. 1989). A causa de pedir, nas ações declaratórias negativas, é o fato jurídico cuja existência se nega. Por isso é que se pode afirmar a identidade das ações, declaratória negativa, proposta pelo indigitado devedor, e declaratória positiva, proposta pelo sedizente credor.

A ação declaratória de autenticidade ou de falsidade de documento tem a particularidade de provocar juízo que recai unicamente sobre fato. Não há pedido de declaração de direito subjetivo, do que decorre a inexistência de causa de pedir, embora se exija a existência do interesse de agir que, porém, não é elemento identificador da ação. Considere-se a sentença que, acolhendo o pedido do autor, "declara que o docu- mento X é autêntico". É fácil observar que a ação, assim julgada procedente, prescinde de qualquer outro elemento para sua identificação.

No que tange à ação declaratória da paternidade, pergunta-se: "Se alguém propõe a investigatória alegando concubinato (art. 363 , I, do CCB) entre a mãe do investigante e o investigado, poderia o juiz, não obstante a falta de prova do concubinato, julgar procedente a ação porquanto, na instrução, se provou a existência de relações sexuais entre aquelas pessoas na época própria da concepção? E indicando o autor, desde logo, na inicial, o concubinato essas relaçōes sexuais (art. 363, II, do CCB), ter-se-ia cumulação de ações ou uma ação com dois fundamentos? Inclina-se Ovidio A. Baptista da Silv pela última solução e aduz: 'a circunstância de estarem os fundamentos de uma mesma demanda distribuídos por dois ou mais dispositivos legais, não implicará que existam necessariamente tantas açōes quantos sejam os preceitos legais em causa.' Existe interessante acórdão sustentando que, rejeitada a alegação de concubinato (art. 363 , I, do CCB), é possível, sem ofensa à causa de pedir, acolher a ação sob o fundamento de relações sexuais (art. 363, II, do CCB). Evidentemente, no concubinato se presumem as relações sexuais entre os concubinos." (Araken de Assis. Cumulaşão de aşões. pág. 121). De minha parte, não teria dúvida em subscrever o acórdão. É que, hoje, há de se entender que a ação declaratória da relação jurídica de paternidade natural tem como causa de pedir única o fato jurídico da paternidade, na concepção do filho. O concubinato (Código Civil, art. 363, I), o rapto (art. 363, II) não passam de indícios que servem à prova da paternidade. Apenas se poderia destacar como causa autônoma o "escrito daquele a quem se atribui a paternidade, reconhecendo-a expressamente", atribuindo-se-lhe a natureza de negócio jurídico e não de simples declaração de ciência. A indicação expressa de indícios únicos, a partir dos quais se poderia presumir a paternidade, é resquício do passado: tratava-se, por um lado, de resguardar o patri- mônio da família legítima e atendia-se, por outro, à deficiência dos meios probatórios, somente superada com as modernas descobertas da genética.

Funda-se indiscutivelmente em negócio jurídico a ação declaratória da paternidade por adoção.

A sentença pode declarar que o prédio $X$ é de propriedade do autor $e x v i$ do registro da escritura $\mathrm{Y} / e x$ vi do registro do contrato $\mathrm{Z}$ /por herança de $\mathrm{B} /$ por herança de $\mathrm{C} /$ por usucapião. Cada um desses fatos constitui causa de pedir distinta. Nas ações reais, a causa de pedir não é a relação jurídica invocada, mas o fato gerador do direito real É a teoria da substanciação, que se adota. Também há diversidade de causa de pedir, na declaração de existência de relação de locação, ex vi do contrato $\mathrm{X}$ ou ex vi do contrato $\mathrm{Y}$.

Se peço a declaração de nulidade da cláusula de juros compostos, constante do contrato $\mathrm{X}$ (porque vedada por lei), ou a declaração de que o débito $Y$ não comporta correção monetária (porque não autorizada por lei), basta o pedido para identificar a ação, porque, como vimos, a norma abstrata invocada pelo autor não é elemento identificador da ação. Confirma-se, assim, o caráter meramente acidental da causa de pedir.

\section{Ações condenatórias}

A sentença condenatória supõe prestação devida pelo réu e cominação de execução. Dessa cominação é que decorre a natureza de título executivo que tem a sentença condenatória. Assim, no pedido de sentença condenatória, podem-se distinguir, além da causa de pedir: (a) a natureza do provimento solicitado (condenação); (b) o conteúdo ou teor do provimento, que compreende a prestação devida pelo réu (ato devido) e o objeto da prestação (geralmente dinheiro); (c) a cominação, quase sempre oculta (sob pena de execução); (d) a causa de pedir.

Examinamos, a seguir, alguns casos de sentenças condenatórias. 
a) Condenação do réu/a pagar ao autor quantia igual ao valor dos danos sofridos pelo veículo X (sob pena de execução)/ porque culposamente os causou - porque proprietário do veículo que os causou - porque segurador. Cada um desses porquês constitui causa de pedir distinta.

b) Condenação do réu/a indenizar os danos estéticos sofridos pelo autor/(sob pena de execução)/porque transportador porque culposamente os causou.

Já demonstramos acima que, proposta ação fundada na culpa, pode o juiz condenar o réu com fundamento na responsabilidade objetiva do transportador, mas que a recíproca não é verdadeira. Por um lado, não seria razoável condenar-se o réu com fundamento em fato (imprudência, negligência ou imperícia) de que não foi chamado a se defender: o cerceamento de defesa seria manifesto; de outro, não seria razoável impedir-se o autor, que não conseguiu demonstrar a existência do contrato de transmonstrar a existência do contrato de trans-
porte, de propor depois uma segunda ação, agora com fundamento em outro fato, ou seja, a culpa da parte adversa.

c) Condenação do réu/a pagar ao autor a quantia de 1.000 , correspondente ao aluguel de setembro do prédio $X /$ (sob pena de execução)/porque locatário - porque fiador.

Não há mudança da causa de pedir, se o autor, na inicial, afirma a existência de contrato escrito e se vem a comprovar contrato apenas verbal. Pode ocorrer que haja duas relações contratuais distintas, v.g., dois contratos de fiança. Então, cada um deles constituirá uma causa de pedir distinta.

d) A execução fundada em cambial e a ação condenatória, fundada no contrato subjacente, não são idênticas. Não só o pedido imediato é diverso (execução, condenação), como também a causa de pedir, porque cambial obriga por si só, independentemente da existência do negócio causal.

e) Conforme Schwab, duas são as causas de pedir, no caso de alguém demandar pagamento do preço de mercadorias, com base em contrato de compra e venda e em instrumento de reconhecimento dessa mesma dívida. (El objeto litigioso en el proceso civil. Buenos Aires, Europa-América, 1968, p.103). Sustenta contudo, que se trata de uma só ação, porque, segundo sustenta, as ações se identificam tão-só pela pretensão processual, ou seja, pelo pedido formulado pelo autor. Essa tese é insustentável perante o Direito brasileiro. Pode-se, porém, concordar com a conclusão, visualizando-se o instrumento de confissão de dívida como simples meio de prova do alegado contrato de compra e venda.

f) Não há alteração da causa de pedir, mas apenas mudança do ponto de vista jurídico, no caso de o autor pedir a condenação do réu a pagar o preço do vinho que the vendeu e, em face da alegação de nulidade do contrato, pleitear a condenação com base em enriquecimento ilícito. Os fatos alegados permanecem os mesmos. O que muda é sua qualificação jurídica.

\section{Ações constitutivas}

No pedido de sentença constitutiva podem-se distinguir, além da causa de pedir: a natureza (constitutiva) e o teor do provimento solicitado, compreendendo este o objeto do provimento (v.g., o contrato X) e o transformado, isto é, o estado jurídico novo, decorrente da sentença.

Examinamos a seguir alguns casos de sentenças constitutivas:

a) O contrato $X$ (objeto do provimento) é anulado (transformado), porque celebrado por menor sem autorização do pai - porque houve coação do contratante A - porque houve dolo do mesmo contratante - porque houve erro do contratante $B$ - porque houve fraude contra credores.

Em princípio, cada um desses fatos indicados constitui causa de pedir autônoma. Podemos, entretanto, abrir exceção para como vício de vontade é a falsa representação à qual uma pessoa é induzida por malícia, ardil ou fraude de outrem. A diferença básica entre o erro e o dolo consiste em ser espontâneo o primeiro e provocado o segundo. $\mathrm{O}$ erro deriva de uma falta de atenção ou de períci do agente. No dolo é a atividade de outrem que ardilosamente induz o agente a uma falsa representação" (Arnold Wald. Curso de Direito Civil Brasileiro. Introduşão e Parte Geral. $5^{a}$ ed. São Paulo, Revista dos Tribunais, 1987. pág. 173). Ora, o dolo é irrelevante se não produziu o erro e, por outro lado, se houve erro essencial, podemos prescindir do dolo. Assim, o que se apresenta como fundamental é o erro. A dúvida sobre a caracterização de uma hipótese como de dolo ou de erro diz respeito apenas à qualificação jurídica dos fatos e, como tal, não altera a causa de pedir.

b) A sociedade conjugal (objeto do provimento) é desconstituída (transformado) por injúria grave consistente no ato $\mathrm{Y}$ (Lei 6.515 , de 26.12 .77 , art. $5^{\circ}$ ). "A separação judicial pode ser pedida por um só dos cônjuges quando imputar ao outro conduta desonrosa ou qualquer ato que importe em grave violação dos deveres do casamento e tornem insuportável a vida em comum."

Cada ato suscetível de qualificar-se como injúria grave constitui causa autônoma para a desconstituição. Em se tratando, porém, de atos da mesma natureza (v.g., dois adultérios, ainda que com diferentes parceiros), há que se entender que o autor, vencido, não poderá, em ação subseqüente, alegar fato contemporâneo, que haja omitido na primeira, por força do artigo 474 do Código de Processo Civil.

Discordamos, pois, de Araken de Assis, que afirma a eficácia preclusiva da sentença, ainda que os fatos tenham natureza diversa, como o adultério e a embriaguez.

Embora discordando, transcrevemos sua lição:

" O direito à separação se encontra formulado genericamente (...) com a locução 'grave violação dos deveres do casamento' que torne insuportável a vida em comum. Vários conjuntos de fatos se amoldam ao tipo genérico: o adultério e a embriaguez escandalosa, pela gravidade que assumem na convivência social, tradicionalmente exemplificam a quebra dos deveres impostos ao cônjuge pelo casamento. Um e outro possuem sucessos históricos próprios, inconfundiveis para o efeito de incidência na norma, e não necessariamente coincidentes, mbora se mostre possível imaginar o adul tério indecoroso do bêbado. Toda vez, porém, que o conjunto circunstancial delinear e marcar adultério e embriaguez, em distintas ações imputáveis ao réu, à medida que o direito subjetivo à separação se afigure único ('grave violação dos deveres do casamento'), esgrime o eventual autor da demanda com duas ações materiais, destacá veis perfeitamente uma da outra, e não uma ação com dois fundamentos. Basta lembrar que o adultério ou a embriaguez, apartados, funcionariam, tout court, como causa de pedir da separação. Em cada uma delas, acodem uma série de sucessos históricos, detalhes e eventos, p. ex., dia, hora e local do ato violador, e a demonstração da insuportabilidade da vida conjugal trazida pelo fato, que colorirá a causa de pedir. Estas circunstâncias não admitem variação, adição ou alteração sem importar a verdadeira modificação da causa petendi, vedada no art. 264 do CPC.

Ainda uma vez, sem embargo da enfadonha repetição, se insiste que a eficácia preclusiva da coisa julgada, face ao disposto no art. 474 do CPC, abrangerá inelutavelmente todos os fatos jurídicos deduzíveis na ação de separação (adultério, embriaguez e qualquer outro apto a incidir na regra), tenham, ou não, sido deduzidos na demanda." (Araken de Assis. Cumulação de ações. pág. 124-5).

c) A sentença $X$ (objeto do provimento) é rescindida (transformado), porque proferida por juiz absolutamente incompetente porque proferida por juiz impedido - porque proferida com violação de literal disposição de lei - por erro de fato. Cada um desses fundamentos constitui causa de pedir autônoma. Trata-se de fatos de natureza diversa, motivo por que, em tese, a rejeição da ação, por um fundamento, não impede outra ação, com diversa causa de pedir. Aí, o curto prazo de decadência, que é de dois anos, é que torna dificilmente verificável a hipótese. A eficácia preclusiva do artigo 474 do Código de Processo Civil é invocável somente em se tratando de fatos de idêntica natureza, como no caso de se invocar violação de um e depois de outro dispositivo legal. 
Costuma-se dizer que a sentença constitutiva contém declaração do direito formativo do autor. Segundo Ovídio Baptista da Silva é esse elemento declaratório que transita materialmente em julgado. Tal direito, porém, integra a causa de pedir, e não o pedido, sendo, pois, mais correto afirmar-se, com José Carlos Barbosa Moreira, que aquilo que transita em julgado é o conteúdo da sentença, isto é, a transformação por ela operada. Certo, o novo estado, criado pela sentença, é modificável por fato superveniente, mas não se pode pôr em dúvida, por efeito da coisa julgada material, o fato da transformação operada pela sentença.

\section{Ações mandamentais}

$\mathrm{Na}$ sentença mandamental se distinguem: a) a natureza do provimento solicitado (ordem ou autorização); b) o destinatário, isto é, a pessoa que deve cumprir a ordem ou tolerar o ato autorizado; c) o conteúdo do ato, que compreende o ato ordenado, proibido ou autorizado e seu objeto (a pessoa ou coisa que sofre os efeitos do ato); d) a causa de pedir. Ao destinatário se impõe dever de fazer ou tolerar. A pessoa que apenas sofre os efeitos, como aquele que é preso em cumprimento à ordem de prisão, é objeto do ato.

As ações mandamentais não apresentam particularidades de monta, no que pertine aos elementos da ação.

São exemplos de sentenças mandamentais:

a) a que determina seja o réu (que, aí, é objeto) posto em liberdade, por nulidade do decreto de prisão (causa de pedir);

b) a que determina seja aceita a matrícula de aluno em estabelecimento de ensino;

c) a que determina o arresto ou o seqüestro de bens do réu;

d) a que autoriza o levantamento de depósito judicial ou a efetivação de obras em coisa litigiosa.

\section{Ações executivas}

Desde Pontes de Miranda se põe a distinção entre as ações executivas stricto sensu (compreendendo as ações de execução, apontadas como tais no Código de Processo Civil, fundadas em título executivo judicial ou extrajudicial) e as ações executivas lato sensu, correspondentes às açōes de conhecimento em que a eficácia condenatória da sentença é tal que permite a execução na mesma relação processual. Trata-se, em última análise, de ações mistas, de conhecimento e de execução. Sem essa categoria, torna-se inexplicável, por exemplo, a liminar em ação de reintegração de posse, que não constitui medida cautelar (pois não supõe periculum in mora), mas adiantamento da execução. Como adiantar-se execução num processo só de conhecimento?

São ações executivas lato sensu as possessórias, a de despejo e, de um modo geral, as que visam a repor no patrimônio do autor algo seu, como a ação reivindicatória.

Diz Ovídio Baptista da Silva: "De um modo geral, então, pode-se dizer que a execução das obrigações de restituir coisa certa, no Direito brasileiro, promove-se por meio de uma demanda especial, existente no processo de conhecimento, a qual contém, dentre suas eficácias próprias, a eficácia executiva, capaz de ensejar a execução na mesma relação processual.

A estrutura de nosso processo de execução forçada está predisposta para servir de instrumento à realização dos direitos de crédito $e$ não deve, sob pena de graves desvantagens, ser estendida a outras situações que não guardam semelhança com o direito obrigacional." (Notas sobre a execução das obrigações de entregar coisa certa. Ajuris, Porto Alegre, (17): 5-27, nov. 1979. Ver também, do mesmo autor, Reivindicação e sentença condenatória, $A j u$ ris, Porto Alegre, (41): 142-86, nov. 1987).

No pedido de execução podem-se distinguir: a) a natureza do provimento solicitado (ato executivo); b) o conteúdo do provimento, que compreende o ato solicitado (imissão ou reintegração na posse, busca/apreensão/entrega, penhora e alienação de bens do réu) e o objeto deste (o imóvel $\mathrm{X}$, a coisa móvel $Y$ ), os bens concretamente arrestados ou penhorados; d) a causa de pedir, isto é, o título executivo (que geralmente é, sem que isso seja essencialmente necessário, um escrito).

Examinamos, a seguir, alguns casos de ações executivas.

a) Condenação do réu a entregar ao autor o imóvel $\mathrm{X} /$ sob pena de despejo/porque não pagou o aluguel do mês de setembro porque o autor dele necessita para uso próprio - porque o autor dele necessita para uso de descendente - porque o autor denunciou a locação (denúncia vazia) - porque ocorreu sublocação não-consentida.

No caso de denúncia da locação, não se exigindo prévia notificação, é a citação que dá ciência ao locatário da vontade do locador e o constitui em mora. Tem-se, então, a particularidade de surgir a ação de direito material depois de proposta a ação processual.

A denúncia, ainda que vazia, opera a resolução do contrato, inas não extingue a locação, que persiste até a desocupação do imóvel. Por isso, os alugueres são devidos até a entrega das chaves.

Pode ocorrer que a Lei defira a retomada para uso próprio, ou de ascendente ou descendente, apenas ao proprietário. Ainda assim, a ação de despejo não será declaratória da propriedade, motivo por que, na inicial, poderá o locador limitar-se a alegá-la, sem indicar o fato que a gerou, embora possa eventualmente ter de comprová-lo, se o réu contestar o domínio, caso em que o juiz se pronunciará a respeito, incidenter tantum.

$\mathrm{Na}$ verdade, a ação de despejo não é sequer declaratória da locação, motivo por que, decretado o despejo, pode o réu, em posterior ação de cobrança de aluguéis, discutir a própria existência da locação, declarada incidenter tantum.

b) Condenação do réu/a entregar ao autor o imóvel X/(sob pena de execução)/porque esbulhador - porque proprietário o demandante e ilegítima a posse do demandado.

No caso de denúncia de comodato por prazo indeterminado, cabe ação de reintegração de posse, porque ela opera a extinção do contrato, constituindo esbulho a recusa do réu a devolver a coisa emprestada.
A ação de reivindicação não é apenas condenatória. É também declaratória da propriedade. Por isso, a causa de pedir não é a propriedade, mas o fato que a gerou. Já vimos que, nas ações reais, a causa de pedir não é a relação jurídica invocada, mas o fato gerador do direito real, pois é a teoria da substanciação a adotada por nosso Código de Processo Civil. "Os fatos jurídicos relevantes à configuração do domínio, vale dizer, a causa da sua aquisição, se revelam imprescindíveis. Assim, o autor que reivindica com fundamento em testamento e compra e venda cumula duas ações." (Araken de Assis, Ibid. p. 126)

\section{Identidade da ação}

modificação da demanda

O autor deve indicar, na petição inicial, os elementos subjetivos e objetivos da ação, além do fato de que decorre seu interesse de agir.

O Código exige a indicação do fato e dos fundamentos jurídicos do pedido (art 282 ,III). Como é ao juiz que incumbe a qualificação jurídica dos fatos (iura novit curia), a indicação destes, mais do que a dos fundamentos jurídicos do pedido, é que assume relevância.

Não raro, da simples enunciação dos fatos já se pode deduzir qual seja a pretensão processual do autor. Aliás, em ações de acidente do trabalho, tem-se relegado a um segundo plano o pedido formulado pelo autor. Qualificado o fato como acidente do trabalho, concede-se ao requerente o benefício cabível (aposentadoria e pecúlio, auxílio-acidente ou auxílio suplementar), conforme caiba, segundo as seqüelas apontadas pela perícia produzida no curso do proces-

É todavia sempre indispensável que o autor indique, na inicial, os fatos de que decorre o direito subjetivo que invoca. Deve, em outras palavras, indicar os fatos constitutivos de seu direito.

$\mathrm{Na}$ verdade, o fato gerador de um direito se constitui não só de seus elementos constitutivos, como também da ausência de ele- 
mentos impeditivos. $O$ fundamento $d a$ ação, porém, é restrito aos fatos constitut vos. A alegação de fatos impeditivos constitui matéria de defesa.

$\mathrm{O}$ artigo 131 do Código de Processo $\mathrm{Ci}_{-}$ vil determina que o juiz atenda aos fatos circunstâncias dos autos, ainda que não ale gados pelas partes. Como o fato gerador d um direito abrange não só os elemento constitutivos mas também a ausência de elementos impeditivos, segue-se que, havendo prova de fato impeditivo, deve o juiz julgar improcedente a ação, ainda que reve o réu, salvo em se tratando de questão que, por lei, exige a iniciativa da parte (CPC, art 128), como as alegações de vício da vontade, por erro, dolo, coação ou fraude.

Não há dúvida de que, permanecendo idênticos os fatos, pode o juiz aplicar norma diversa da invocada pela parte, porque na alegação dos fatos é que reside a causa de pedir (teoria da substanciação). Todavia uma certa variação é permitida, como decorre dos artigos 131 e 462 do Código de Processo Civil, que dispõem, respectivamente:

"O juiz apreciará livremente a prova, atendendo aos fatos e circunstâncias dos autos, ainda que não alegados pelas partes".

"Se, depois da propositura da ação, algum fato constitutivo, modificativo ou extintivo do direito influir no julgamento $d$ lide, caberá ao juiz tomá-lo em consider ção, de ofício ou a requerimento da parte no momento de proferir a sentença."

Trata-se, agora, de estabelecer os limites dessa variação, para o que se levará em consideração as distinções antes apontadas entre fatos simples, fatos complexos e fatos diversos, de igual ou diversa natureza.

a) Alegado o fato fundamental, pode o juiz, de ofício, conhecer de suas circunstâncias e efeitos. Mesmo no processo penal, entende-se que o objeto da investigação permanece o mesmo, quer se afirme tratar-s de homicídio simples ou qualificado e mesmo que se chegue à conclusão de que se configurou o delito de latrocínio. Aliás, da circunstâncias e efeitos do fato, o juiz, de regra, somente pode conhecer na ação proposta. Não se admitiria uma ação que en- volvesse o homicídio de outra envolvendo somente a surpresa, o meio cruel ou a finalidade "para roubar".

Em se tratando de fato complexo, isto é, de fatos diversos mas que só em conjunto produzem o efeito jurídico, é de se admiti que, alegado $O$ fato $X$, conheça o juiz do fato $Y$, que perfaz a unidade geradora do direito. Assim, se o autor propõe ação rei vindicatória, com base no negócio jurídico $Z$, pode o juiz conhecer do fato do registro, alegado ou não, já preexistente à data da propositura da ação ou superveniente.

No caso de eventos diversos, da mesma natureza e conducentes ao mesmo efeito jurídico, é de se admitir que, alegado um fato, conheça o juiz de outro. (Exemplos: em ação de separação, o autor não consegue comprovar o alegado adultério da ré com o parceiro $B$, mas restam cumpridamente provadas suas relações sexuais com $\mathrm{C}$; em ação de despejo, comprova-se que houve sublocacão não consentida para $\mathrm{D}$, e não para $\mathrm{E}$ conforme alegado na inicial). Por isso mesmo, o fato diverso, de idêntica natureza, coberto pela eficácia preclusiva do artigo 474 do Código de Processo Civil: "Passada em julgado a sentença de mérito, reputar-seão deduzidas e repelidas todas as alegações e defesas que a parte poderia opor assim ao acolhimento como à rejeição do pedido." Para os efeitos de nunciação de obra nova, a posse ou propriedade do autor são fatos da mesma natureza. Se o autor, afirmando-se apenas possuidor, é vencido, não pode, depois, propor outra ação, afirmando sua condição de proprietário.

(No caso de eventos diversos, de igual natureza, mas com resultados jurídicos diversos, ainda que iguais, o pedido, e não a causa de pedir, é que entra em jogo. Assim se o locador intenta ação de indenização por danos nas portas, sem dúvida não pode o juiz condenar o réu por danos nas paredes, mas o autor não fica impedido de intentar outra ação, para cobrar os danos não alegados na primeira como deixa claro artigo 294 do Código de Processo Civil)

No caso de eventos diversos de natureza diversa, é fora de dúvida que, alegado um, não pode o juiz conhecer de outro. Assim, proposta ação de despejo por sublocação não consentida, não pode o juiz, evidentemente, decretá-lo porque o réu danificou dolosamente o imóvel. Por isso mesmo, esse segundo fato, de que o juiz não pode conhecer numa primeira ação, pode servir de fundamento para uma segunda, em face da inexistência de coisa julgada.

Tenho por manifestamente equivocada tese de Araken de Assis, que interpreta artigo 474 do CPC no sentido de vedar a renovação do pedido, qualquer que seja causa de pedir (salvo se fundada em fato superveniente). Afirma ele que "à vista dos arts. 128 , primeira parte, e 468 do CPC, a causa não deduzida fica atingida pelo art 474 do CPC e, por decorrência, irremediavelmente preclusa." (Reflexões sobre a eficácia preclusiva da coisa julgada. Ajuris, Porto Alegre, (44):24-44, nov. 1988; Cumulaşão de ações. São Paulo, RT, 1989, p. 93).Não obstante sua assertiva de que tal conclusão não deveria "escandalizar ninguém", tenho-a por escandalosa, num sistema processual que disciplina a exceção de coisa julgada, ligando-a à tríplice identidade das partes, do pedido e da causa de pedir. Para que haveria o juiz de examinar a identidade da causa de pedir se, para pôr termo à nova ação, bastasse a comprovação da identidade de partes e de pedido? O artigo 474 do Código de Processo Civil não pode ser interpretado como uma supernorma, derrogatória de qualquer outra existente no Código. A noção de lide parcial, em que se apóia o autor, diz mais respeito ao pedido do que à causa de pedir. Há o ajuizamento de lide parcia se, vencidas todas as prestações, o auto propõe ação para cobrar apenas uma e, é claro, (o próprio Araken não deixará de concordar), nem por isso estará o juiz autorizado a julgar a lide total, nem haverá que se falar em eficácia preclusiva da coisa julgada.

$O$ regime do fato superveniente ocorrido no curso da ação é o mesmo do fato ocor rido antes e não alegado na inicial. Em outras palavras, o fato superveniente de que o juiz pode conhecer não pode importar total alteração da causa de pedir. Segue-se, pois, que:

a) alegado o fato, pode o juiz conhecer de efeito seu, que se haja verificado no curso do processo. Exemplo: havendo pedido de indenização de danos pessoais decorrentes do ato $\mathrm{X}$ do réu, o efeito "morte da vítima", no curso do processo, pode e deve ser levado em consideração para a fixação da indenização devida;

b) alegado o fato, pode o juiz conhecer do fato conexo, em se tratando de fato com plexo. Exemplo: registro do contrato no curso do processo; vencimento da dívida no curso da ação;

c) pode o juiz conhecer de fato de idêntica natureza do alegado na inicial. Exemplo: proposta ação de despejo por falta de pagamento do aluguel de setembro, o inquilino propõe ação de consignação em pagamento do valor correspondente. Dois anos após, o juiz prolata a sentença, julgando procedente a consignatória e procedente também o pedido porque, desde então, o inquilino não pagou mais nenhum aluguel;

d) se o fato superveniente é de natureza diversa do alegado na inicial, dele não pode o juiz conhecer. Exemplo: a danificação do imóvel pelo inquilino, no curso de ação de despejo fundada em sublocação não consentida.

O regime do fato contemporâneo, mas desconhecido pelo autor, à data da propositura da ação é igual ao do fato superveniente.

É elementar, embora às vezes esquecido, que, pretendendo o juiz conhecer de fato não alegado, deve ouvir o réu e propiciar-lhe a produção de provas, tal como dispõe o artigo 384 do Código de Processo Penal.

\section{Identificação de ações}

Trata-se, agora, não mais de resguardar a identidade de uma ação, mas de confrontar duas, para verificar se uma é repetição da outra.

Nos termos do artigo $302, \S 2 \%$, do Código de Processo Civil, uma ação é idêntica 
à outra quando têm as mesmas partes, a mesma causa de pedir e o mesmo pedido.

Do texto decorre, à uma primeira leitura, que o fato cognoscível em uma ação é necessariamente incognoscível em outra. Efetivamente, se o fato $H$, não alegado, era cognoscível na primeira ação, segue-se que ele não importava alteração completa da causa de pedir. Portanto, alegado agora, em uma segunda ação, está-se a repor causa de pedir que já foi objeto de sentença.

Ocorre que as exigências práticas que determinam a cognoscibilidade de fatos não alegados, na ação em curso, não são as mesmas que determinam a incognoscibilidade dos mesmos fatos, em ação diversa.

Admite-se o conhecimento, na própria ação, de fato não alegado na inicial, primeiro, em função de sua conexão com os que foram alegados e, segundo, por economia processual.

Por outro lado, o que se quer impedir, com a coisa julgada, é sobretudo a rediscussão dos mesmos fatos: discussão sempre difícil e inconclusiva sobre provas e sobre a interpretação de leis e contratos.

Suponha-se ação reivindicatória fundada em contrato. Somente no curso do processo ocorre o registro. Trata-se, aí, de fato complexo (contrato+registro). $O$ fato superveniente do registro é cognoscível na própria ação. Se, todavia, esse fato não é levado ao conhecimento do juiz ou se este entende que, dada a fase em que se encontra o processo, já não cabe levá-lo em consideração, tem-se de admitir a propositura de uma segunda ação, fundada no fato novo, não examinado na sentença anterior.

No caso de ação de indenização proposta por passageiro contra empresa de transporte coletivo, fundada na culpa do motorista, seu preposto, pode-se acolher o pedido com base na responsabilidade objetiva, conforme bem ensina Chiovenda, em lição já antes referida. Todavia, se o juiz se detém apenas no exame da responsabilidade extra-contratual e não se pronuncia sobre o fundamento "contrato de transporte", não seria razoável impedir-se a propositura de uma segunda ação, a pretexto de que, havendo o juiz afirmado a inexistência de culpa, implicitamente teria afirmado a inexistência de qualquer responsabilidade, ainda que obetiva.

Por força do artigo 462 do Código de Processo Civil, o juiz está autorizado a aplicar lei superveniente (v.g., lei de anistia editada no curso de ação anulatória de débito fiscal). Entretanto, não se examinando, na ação em curso, a questão da incidência da lei nova, não seria razoável impedir-se a propositura de uma segunda, a pretexto da existência de coisa julgada, embora nenhum julgamento tivesse havido a respeito.

\section{Conexão}

O Código de Processo Civil estabelece que a competência em razão do valor e do território poderá modificar-se pela conexão, reputando-se conexas duas ou mais ações, quando lhes for comum o objeto ou a causa de pedir.

A reunião de causas, num juízo único, com a prorrogação da competência deste para o conhecimento de ações que, normalmente, seriam submetidas a outro, decorre da necesside lógica e político-jurídica de evitar julgamentos contraditórios, bem como de razões de conveniência, vinculadas ao princípio de economia processual.

Também no que se refere à conexão de causas nosso Código se vinculou à centenária teoria dos três elementos da ação, formulada por Pescatore e difundida sobretudo por Mattirolo.

Há conexão por identidade de causa de pedir, por exemplo, entre a ação ordinária de cobrança de aluguéis e a consignatória desses mesmos locativos. Em uma e em outra ação, a causa de pedir é o contrato de locação. O inadimplemento do locatário, alegado na ação de cobrança, e a recusa do locador, alegada na consignatória, dizem respeito ao interesse de agir, que não é elemento identificador da ação.

Há conexão por identidade de pedido, por exemplo, entre as ações de cobrança do mesmo aluguel, fundadas uma no próprio contrato de locação e a outra em contrato de fiança.
Não há que se levar demasiado à risca a formulação do Código em relação à conexão. Assim, há identidade de pedido nas ações de despejo relativas ao mesmo imóvel, fundadas uma em falta de pagamento e a outra em denúncia vazia. Nesse caso, salvo se contestada a existência da locação, não há possibilidade de sentenças contraditórias: uma não influi na outra, não sendo essencial que se promova a reunião dos pro- cessos (não há nulidade).

Por outro lado, pode haver conexão por um elemento originalmente culto, entre uma ação de execução, fundada em cambial e uma ação de cobrança, fundada no contrato subjacente, como freqüentemente ocorre nos contratos garantidos mediante a emissão de título de crédito. O elemento de conexão se revela com a oposição de embargos à execução. 